\title{
Elaboration of EQID tool for digestive cancer predisposition
}

\author{
Souria Aissaoui ${ }^{1,2 *}$, Stéphane Pinson ${ }^{1}$, Sophie Giraud ${ }^{1}$, Marisa Raymond ${ }^{3}$, Hagay Sobol ${ }^{4}$ and Alain Calender ${ }^{1}$ \\ ${ }^{1}$ Service of Molecular and Medical Genetics, Civil Hospices of Lyon, Lyon, France \\ ${ }^{2} \mathrm{AFCG}$ (AFCG (French Association of Genetic Counselors), Marseille, France \\ ${ }^{3}$ Genetic Counselling Services, Inc., Schenectady, NY, USA \\ ${ }^{4}$ Department of Genetic Oncology, Prevention and Screening, Paoli-Calmettes Institute, Marseille, France
}

\begin{abstract}
Lynch Syndrome is one of the most common diseases that predispose individuals to colorectal cancers. It is caused by mutations in DNA mismatch repair $(M M R)$ genes. Genetic counselling is imperative to assist patients and their families in making decisions around surveillance, treatment, and care. Multidisciplinary committees (MDC) are organized by health professionals and specialists to optimize this process. The aim of the study is to examine the evaluation and improvement of quality decision-making for families with a genetic predisposition to colorectal cancer: based on gene test validation as well as proband and family care management. We observed practices among geneticists are diverse and discordant and not always consistent with recommendations made by France's Institute National du Cancer (INCa). We highlight the use of somatic testing via RER and MMR protein immunohistochemistry. We highlight the need of a computerized tool, that was developed and is now widely disseminated to every collaborating partner of our MDC. This tool will enable us to standardize our decision-making and, by comparing decisions through quality criteria, to differentiate and categorize some patients or families groups. As a result, we can achieve a better justification of care management and family prevention.
\end{abstract}

\section{Introduction}

Lynch syndrome, also known as Hereditary Non-Polyposis Colorectal Cancer (HNPCC) syndrome is a commonly inherited disorder that predisposes patients to colorectal cancers. It is suspected through Amsterdam II criteria [1]. In addition to colorectal cancer, cases of endometrial, small intestine, and urinary tract cancers can also present in these families. Lynch syndrome is defined by mutations in the $M M R$ genes. In at-risk patients, a chromo-colonoscopy is recommended, every 2 years, from the age of 20 years. In addition, an annual gynaecologic surveillance is recommended in women beginning at 30 years of age. The second most common syndrome predisposing to CRC is the Familial Adenomatous Polyposis (FAP), which is caused mainly by mutations in $A P C$ gene. It causes CRC and a high number of polyps [2].

A consultation that includes genetic counselling is mandatory before making a recommendation of genetic testing to an at-risk family. This discussion also should include a surveillance strategy for these patients. Most French genetic centres (76\%) organize multidisciplinary committees (MDC) to bring together medical professionals to help optimize decision-making around care management, taking into account advice from relevant experts and specialists [3]. In the Lyon region of France, one MDC is organized every month. Anecdotal evaluations of these MDCs suggested that its management was not standardized. We, therefore, developed a tool to enable us to evaluate and systemize the MDC. The aim the EQID (Assessment and Improvement of Quality Decision-making within digestive cancer MDCs) Study is to evaluate the quality of decision-making for a given family with digestive cancer risk through the MDC in order to improve family management and optimize the quality of care. In French, the EQID study is known as the EQAD COG Colon (Evaluation et Amélioration de la Qualité de Décision en Comité d'Oncogénétique dédié au Colon) Study.

\section{Patients and methods}

EQID is based on an analysis of nearly 200 patient cases which were discussed within the Lyon region's MDC between 2004 to 2012. These cases arose from families who received a genetic consult during that time in one of our clinics. The patients taken into account were those affected by colon cancer with a putative genetic predisposition, according to family history and well-established criteria published among two major consensus conference focusing HNPCC related digestive cancers [4]: Amsterdam criteria and Bethesda guidelines (positive predictive value and sensitivity recognized). Tumour studies, including examination of microsatellite stability through replication error analysis and immunohistochemistry of MMR proteins, were performed and often drove MDC decision-making. DC decision-making.

First, patient cases were reviewed based on Lynch Syndrome criteria to establish the validity of recommending genetic testing

${ }^{\star}$ Correspondence to Souria Aissaoui, Service of Molecular and Medical Genetics, Civil Hospices of Lyon, Lyon, France, E-mail: souria.aissaoui@chu-lyon.fr

Key words: risk assessment, colorectal cancer, genetic diagnosis, multidisciplinary decision-making, familial cancer management

Received: August 09, 2019; Accepted: August 23, 2019; Published: August 25 2019 
and a comparison between similar pedigrees was undertaken. Then, surveillance recommendations among cases were compared. As schematically represented in Appendix A (study protocol), a comparative study was proposed with patient cases being placed into 1 of 3 groups according to their somatic test status: RER+/IHC+ (Group 1), RER+/ICH- (Group 2), and RER-/IHC- (Group 3).

Different key points have been targeted and validated by the MDC as decisive indicators for a decision-making: 1 ) the nature of tumours of a suspected predisposition, 2) the age of diagnosis, 3) the degree of relationship of relatives with the proband, 4) the availability of somatic tests (RER and IHC) and genetic testing, and 5) the care-management recommended for a patient and his or her family. Taking into account these elements, an electronic tool was developed by a clinical informaticist affiliated with the Lyon region's cancer genetic network and was used to gather and analyse the major criteria of a patient's given decision-making process. It is integrated into the electronic medical record system (Easily software).

\section{Results}

In our center, a genetic consult starts with drawing a family pedigree, searching Amsterdam criteria, and performing somatic testing on the most appropriate tumour sample. Based on this evaluation, we determine whether or not genetic testing is warranted and propose a plan for care management. (Figure 1: Flow chart figure). The probands' main tumour type for which patients have been referred to our consultation are essentially colorectal cancers (51\%), endometrial cancers (10\%), polyposis (8\%) and gastric cancers (4\%). We also find ovarian and cutaneous cancers (less than 2\%) (Figure 2).

\section{Somatic tests results}

We performed 142 somatic tests in 125 families. Less than half of the tested tumours displayed MSI (microsatellite instability). Less than half of tested tumours showed a loss of one or more MMR proteins in immunohistochemistry. Of note, we found MLH1 protein loss of expression in 23 cases, of which methylation of $M L H 1$ gene promotor was studied for only 13 cases $(59.09 \%)$ (Table $1 \mathrm{a})$.

NB: methylation of a gene promotor correlates with loss of expression of the corresponding protein and can exclude a diagnosis of Lynch syndrome if no familial history.

\section{Genetic tests results}

In 59 cases $(30.25 \%)$ a genetic test was performed prior to the MDC. Among these, 34 (57.63\%) were MMR gene tests. Thus, within the MDC, in these cases, discussion focused primarily on patientfamily care management recommendations. After the MDC, decisions were made regarding additional somatic testing recommendations in relatives prior to rediscussion of the patient case in 24 cases (12.31\%). Gene testing was discussed in 74 cases ( $47 \%$, this number is computed by excluding bias due to retrospective request, where only tested patients where sectioned for our study) (Table $1 b$ ).

\section{MMR gene test results and patients/families care management decisions by MDC, based on somatic tests.}

We organized gene test and care management decision through 3 groups (Table 2):

\section{Group 1: RER+/IHC+ cases: 48 cases}

Genetic analysis indication: Among, RER+/IHC+ cases, there were 15 patients that did not meet Amsterdam or Bethesda criteria, but for whom tumour signature was sufficient to validate the recommendation of genetic testing. These criteria offer a very good positive predictive value since more than 50\% (8/15) of tested cases were found to have an MMR gene mutation. However, this value underlines that we are not selective enough.

Among the 33 remaining patient cases presented in the MDC, we discussed 25 genetic testing indications and 4 somatic testing indications (of which 3 included discussions of promotor methylation analysis of the MLH1 gene).

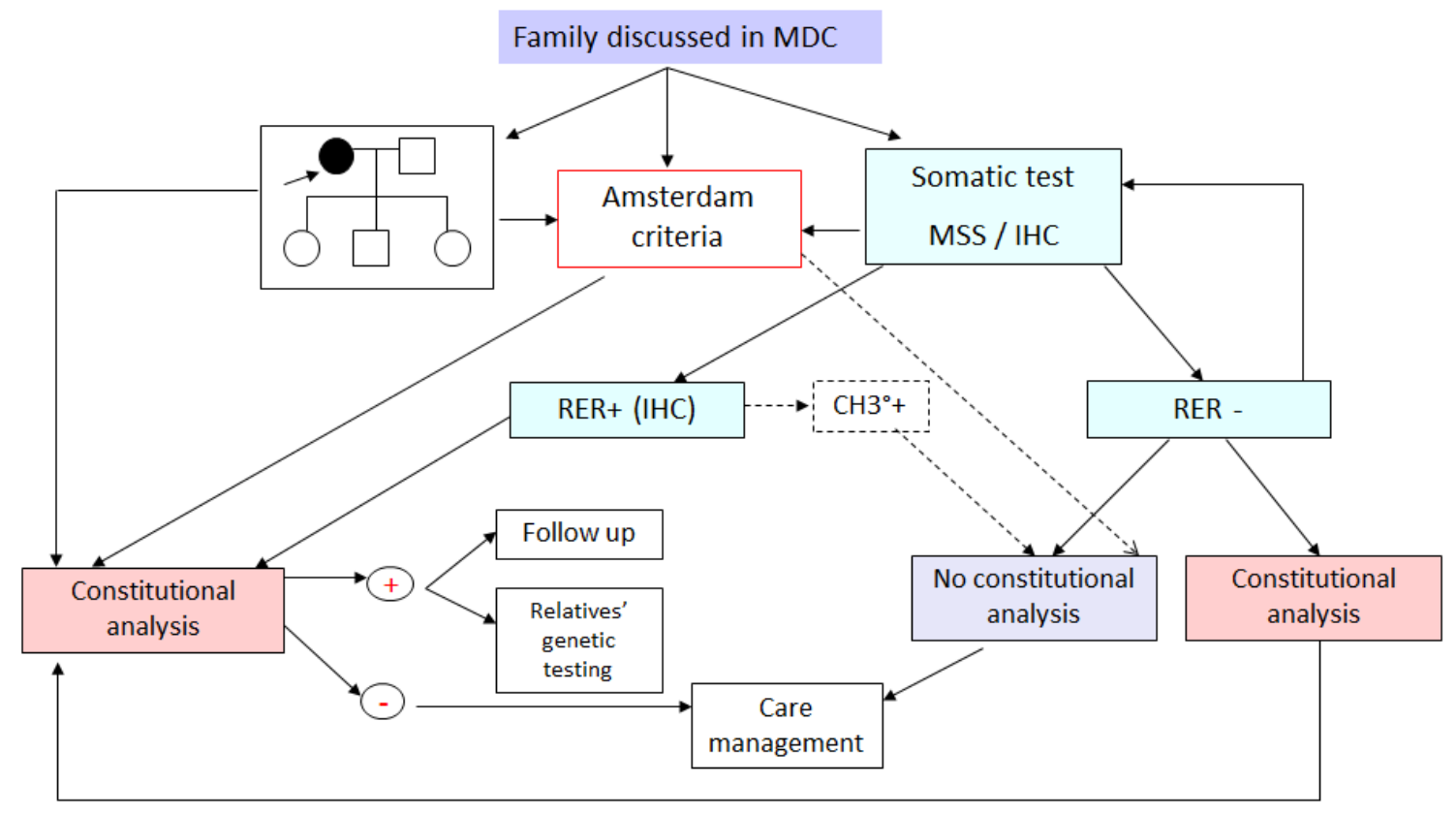

Figure 1. Representation of diagnosis strategy in our Lyon team.

RER: Replication Error. RER+: microsatellite instability. RER-: stability of microsetellites. $\mathrm{CH}^{\circ}+$ : promotor methylation. IHC: immunohistochemistry. MDC: multidisciplinary committee.

$+:$ mutation identified. - : no mutation 


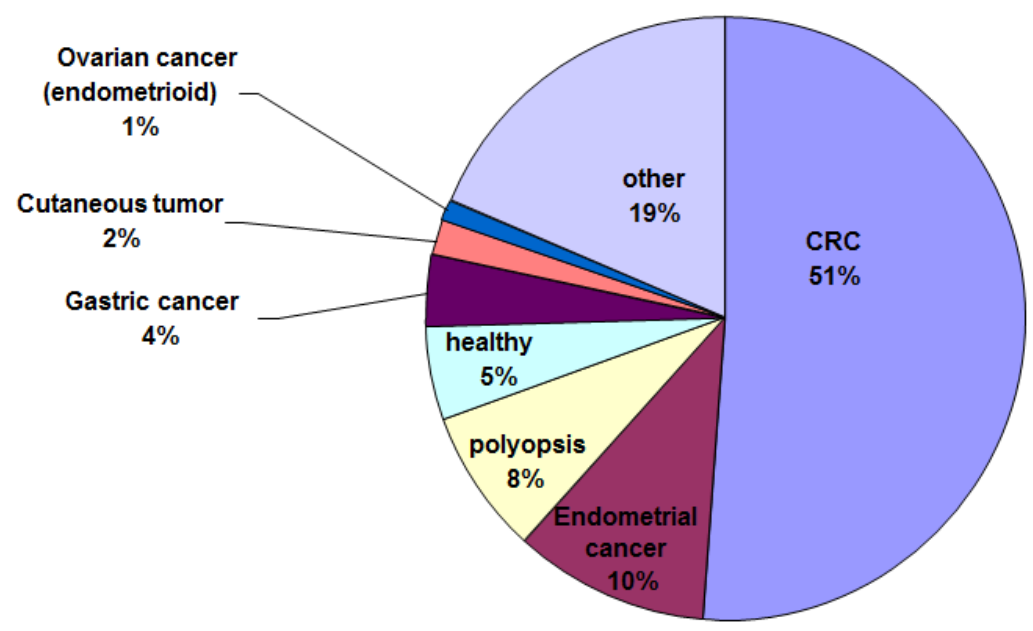

\begin{tabular}{|lr}
\hline prospectif & 159 \\
rétrospectif & 36 \\
total & 195 \\
\hline
\end{tabular}

\section{Population}

\begin{tabular}{lr}
\hline \hline MALE & 81 \\
FEMALE & 111 \\
$?$ & 3 \\
total & 195 \\
\hline Sexe. & \\
\hline \hline CRC & 104 \\
endometrial & 21 \\
polyopsis & 16 \\
unaffected & 10 \\
Other digestive & \\
lesion* & 8 \\
cutaneous lesion & 4 \\
Ovaarian & \\
(endometrioidal) & 2 \\
Other ** & 38 \\
\hline total & 195 \\
*essentially stomac cancer, lampulloma \\
*tagdenomatous polype/familal cancer
\end{tabular}

Figure 2. Representation of main tumors of the propositus

Table 1. A) somatic test details. B) Details of somatic/constitutional testings realized before and after MDC

\begin{tabular}{|c|c|c|c|c|}
\hline A) & Family's tumours & & Tumour 1 & Tumour 2 \\
\hline \multirow[t]{7}{*}{ RER status } & mss & \multirow{2}{*}{76} & 63 & 9 \\
\hline & msi-1 & & 4 & 0 \\
\hline & $\mathrm{msi}$ & \multirow{2}{*}{38} & 6 & 1 \\
\hline & $\mathrm{msi}-\mathrm{h}$ & & 28 & 3 \\
\hline & failed or impossible & \multirow{2}{*}{13} & 9 & 0 \\
\hline & & & 4 & 0 \\
\hline & total & & 114 & 13 \\
\hline \multirow[t]{13}{*}{ IHC status } & ihc+ & 53 & 48 & 5 \\
\hline & ihc- & 77 & 68 & 9 \\
\hline & & total & 116 & 14 \\
\hline & MLH1 loss & 23 & 21 & 1 \\
\hline & MSH2 loss & 24 & 21 & 3 \\
\hline & MSH6 loss & 26 & 23 & 3 \\
\hline & PMS2 loss & 12 & 11 & 1 \\
\hline & & total & 76 & 8 \\
\hline & $\mathrm{CH}^{\circ}+$ & 3 & 3 & 0 \\
\hline & $\mathrm{CH}^{\circ}{ }^{\circ}-$ & 7 & 7 & 0 \\
\hline & $\mathrm{CH} 3$ failed & 3 & 3 & 0 \\
\hline & CH3 impossible & 0 & 0 & 0 \\
\hline & $\mathrm{CH} 3$ not done & & 13 & 0 \\
\hline
\end{tabular}

mss : microsatellites stability, msi : microsatellites unstability (msi-high, or msi-low). $\mathrm{CH} 3^{\circ}$ : methylation study of $M L H 1$ gene promotor. $\mathrm{CH} 3^{\circ}+:$ methylation, $\mathrm{CH}^{\circ}-$ : no methylation. IHC: immunihistochemistry. IHC+: loss of the expression of 1 (or more) MMR protein in IHC. IHC-: no loss of expression of MMR protein.

\begin{tabular}{|c|c|c|c|c|}
\hline B) & \multicolumn{3}{|c|}{ Before MDC (performed) } & After MDC (to perform) \\
\hline bio (RER/IHC) & \multicolumn{3}{|c|}{$72,82 \%$} & $12,31 \%$ \\
\hline CH3* & \multicolumn{3}{|c|}{$59,09 \%$} & l \\
\hline Gene & \multicolumn{3}{|c|}{$30,25 \%$} & $46,54 \% * *$ \\
\hline \multirow[t]{2}{*}{ MMR } & $57,63 \%$ & MMR+ & $23,73 \%$ & \multirow{2}{*}{$51,35 \%$} \\
\hline & & MMR- & $33,90 \%$ & \\
\hline \multirow[t]{2}{*}{ APC } & $16,95 \%$ & $\mathrm{APC}+$ & $3,39 \%$ & \multirow{2}{*}{$10,81 \%$} \\
\hline & & APC- & $13,56 \%$ & \\
\hline \multirow[t]{2}{*}{ MYH } & $22,03 \%$ & MYH+ & $1,69 \%$ & \multirow{2}{*}{$36,49 \%$} \\
\hline & & MYH- & $20,34 \%$ & \\
\hline Other & \multicolumn{3}{|c|}{$15,25 \%$} & $3,76 \%$ \\
\hline MDC discussion & \multicolumn{3}{|c|}{ Care management } & Analysis validation \\
\hline \multicolumn{5}{|c|}{$\begin{array}{l}\text { *Search for methylation of } M L H 1 \text { promotor when there is a loss of expression in immuno - histochemistry. ** }(74 / 159) \text { : The bias is related to the removed retrospective data (only the } \\
\text { tested cases are selected). In some cases, if research of } M M R \text { gene defects is negative, } A P C \text { gene analysis is proposed by MDC. MDC: multidisciplinary committee. CH3: research of } \\
\text { methylation. +: presence of mutation, - : absence of mutation. }\end{array}$} \\
\hline
\end{tabular}


Table 2. Group 1, Group 2, Group 3 cases analysis

\begin{tabular}{|c|c|c|c|c|c|}
\hline \multicolumn{6}{|c|}{ Group 1: analysis Indication, RER+/IHC+ cases: 48 cases } \\
\hline $\begin{array}{l}\text { met criteria } \\
\text { nb of case }\end{array}$ & Amsterdam II & Bethesda & none & TOTAL RER+/IHC+ & \\
\hline MMR + & 2 & 4 & 2 & 8 & \multirow{2}{*}{15} \\
\hline MMR - & & 6 & 1 & 7 & \\
\hline Not tested (To discuss) & 1 & 20 & 12 & 33 & \\
\hline \multirow[t]{2}{*}{ To test } & 1 & 19 & 5 & 25 remaining & \\
\hline & 3 & 30 & 15 & & \\
\hline \multicolumn{6}{|c|}{ Group 1: care management decision } \\
\hline \multirow{4}{*}{$\begin{array}{c}\text { MMR+ } \\
(8 / 15) \\
2 \text { women } \\
6 \text { men }\end{array}$} & & No of cases & Rhythm & Age at the beginning & remark \\
\hline & Colonoscopy & 8 & $/ 2 \mathrm{y}$ & 20 & \\
\hline & Gastroscopy & 2 & $/ 2 \mathrm{y}$ & 1 & No gastric cancer in family \\
\hline & Vaginal echography & 6 & $/ 1 \mathrm{y}$ & 30 & \\
\hline \multirow{10}{*}{$\begin{array}{l}\text { MMR- }(7 / 15) \\
5 \text { women } \\
2 \text { men }\end{array}$} & & No of cases & Rhythm & Age at the beginning & remark \\
\hline & \multirow{2}{*}{ Colonoscopy } & 1 & type Lynch & & $\begin{array}{l}23 \mathrm{y} \text { before isolated } \mathrm{kc} \text { at } \\
43 \mathrm{y}\end{array}$ \\
\hline & & 1 & $/ 3 \mathrm{y}$ & $*$ & $\begin{array}{l}* \text { Already care-managed, } \\
\text { isolated kc } 42 \text { y }\end{array}$ \\
\hline & gastroscopy & 0 & & & \\
\hline & Vaginal echography & 0 & & & 1 endometrial cancer! \\
\hline & nothing & 4 & & & $\begin{array}{l}2 \text { healthy, } 1 \text { study inclusion, } 2 \\
\text { isolated cancers }\end{array}$ \\
\hline & other & 1 & & & $\begin{array}{l}\text { Renal echography at } 30 \mathrm{y} \text {. } \\
\text { (patient:adenomatous } \\
\text { colorectal polyp, mother } \\
2 \text { crc }<50 \mathrm{y}, 1 \text { third degree } \\
\text { relative: urothelial cancer } \\
\square \text { tobacco?) }\end{array}$ \\
\hline & \multirow{2}{*}{ colonoscopy } & 2 & As Lynch & & running test \\
\hline & & 4 & 1 control & & running test \\
\hline & nothing & 27 & & & running test \\
\hline \multicolumn{3}{|c|}{$\begin{array}{l}2 \text { cases of gastric cancers (late, } 1^{\text {st }} / 2^{\text {nd }} \text { degree relatives) } \\
\text { No surveillance recommended for upper gastrointestinal tract }\end{array}$} & \multicolumn{3}{|c|}{2 bladder cancer (in $1^{\text {st }}$ degree relative, at $48 \mathrm{y}$ ): No surveillance recommended } \\
\hline \multicolumn{6}{|c|}{ Group 2: analysis Indication, RER+/IHC- Cases: 8 family cases } \\
\hline met criteria & Amsterdam II & Bethesda & none & TOTAL RER+/IHC- & \\
\hline $\mathrm{MMR}+$ & 3 & 1 & & 4 & \multirow{2}{*}{5} \\
\hline MMR - & & 1 & & 1 & \\
\hline Not tested (o discuss) & & 3 & & & \\
\hline \multirow[t]{2}{*}{ To test } & & 3 & & remaining 3 & \\
\hline & 3 & 5 & & & \\
\hline \multicolumn{6}{|c|}{ Group 2: care management decision } \\
\hline \multirow{4}{*}{$\begin{array}{c}\mathrm{MMR}+(4 / 5) \\
4 \text { women } \\
0 \text { man }\end{array}$} & & $\begin{array}{l}\text { nb of } \\
\text { cases }\end{array}$ & rythm & $\begin{array}{l}\text { Age at the } \\
\text { beginning }\end{array}$ & Remark \\
\hline & Colonoscopy & 4 & as Lynch & $20-25$ & \\
\hline & gastroscopy & 0 & & & $\begin{array}{c}\text { one } 1^{\text {st }} \text { degree relative:crc. } \\
\text { and one } 2^{\text {nd }} \text { degree } \\
\text { relative at } 35 \mathrm{y}\end{array}$ \\
\hline & Vaginal echography & 4 & & 30 & \\
\hline \multirow{6}{*}{$\begin{array}{c}\text { MMR- }(1 / 5) \\
1 \text { woman }\end{array}$} & & $\begin{array}{l}\text { nb of } \\
\text { cases }\end{array}$ & rythm & $\begin{array}{l}\text { Age at the } \\
\text { beginning }\end{array}$ & Remark \\
\hline & Colonoscopy & 1 & as Lynch & $20-25$ & isolated $\mathrm{kc}$ at $45 \mathrm{y}$ \\
\hline & gastroscopy & & & & \\
\hline & Vaginal echography & & & & \\
\hline & nothing & & & & \\
\hline & other & & & & \\
\hline \multicolumn{6}{|c|}{ Groupe 3: analysis Indication, RER-/IHC- cases: 59 family cases } \\
\hline $\begin{array}{l}\text { met criteria } \\
\text { nb of case }\end{array}$ & Amsterdam II & Bethesda & none & TOTAL RER-/IHC- & \\
\hline \multicolumn{6}{|l|}{ MMR + } \\
\hline MMR - & & 8 & $3 *$ & 11 & \\
\hline Not tested (to discuss) & 6 & 23 & 8 & 37 whose 6 bio & \\
\hline \multirow[t]{2}{*}{ To test } & 2 & 6 & 3 & 11 & \\
\hline & 8 & 37 & 14 & & \\
\hline
\end{tabular}




\begin{tabular}{|c|c|c|c|c|c|}
\hline \multicolumn{6}{|c|}{$\begin{array}{l}* 1 \text { isolated case at } 54 \mathrm{y} \\
1 \text { healthy with father TPM since } 50 \mathrm{y} \\
1 \text { adenomatous colorectal polyp, with one } 2 \text { nd degree } \\
\text { relative with crc }\end{array}$} \\
\hline \multicolumn{6}{|c|}{ Group 3: care management decision } \\
\hline \multirow{7}{*}{$\begin{array}{l}\text { MMR- }(11 / 59) \\
4 \text { women } \\
7 \text { men }\end{array}$} & \multirow{5}{*}{ Colonoscopy } & nb cases & rythm & Age at the beginning & remark \\
\hline & & 2 & as Lynch & 20 & 2 Amsterdam $(=\mathrm{Sd} X)$ \\
\hline & & 4 & $/ 3 y$ & $20 \ldots 35$ & $\begin{array}{c}1 \text { indigo (between } 5 \text { and } 7 \\
\text { years before the youngest } \\
\text { cancer) }\end{array}$ \\
\hline & & 2 & $/ 3-5 y$ & $30 \ldots 40$ & $\begin{array}{l}15 \text { and } 4 \text { years before the } \\
\text { youngest cancer }\end{array}$ \\
\hline & & 3 & $15 \mathrm{y}$ & $30 \ldots 35$ & $\begin{array}{l}1 \text { duodenum (pas de loc } \\
\text { duod) 1indigo (family with } \\
\text { polyps), between } 7 \text { and } 9 \text { y } \\
\text { before the youngest cancer. }\end{array}$ \\
\hline & gastroscopy & 0 & & & $\begin{array}{c}1 \text { case at } 77 \text { y }\left(2^{\text {nd }} \text { degree }\right. \\
\text { relative })\end{array}$ \\
\hline & Vaginal echography & 2 & & & as Lynch, no uterine cancer! \\
\hline \multirow{9}{*}{$\begin{array}{l}\text { Not tested: no analysis } \\
\text { indication } \\
(37 / 59) \\
26 \text { women } \\
11 \text { men }\end{array}$} & \multirow{5}{*}{ Colonoscopy } & nb cases & rythm & Age at the beginning & remark \\
\hline & & 12 & $15 \mathrm{y}$ & $20 \ldots 45$ & $\begin{array}{c}\text { Between } 2 \text { and } 14 \text { y before } \\
\text { the youngest cancer. } 2 \\
\text { duodena } \\
1 \text { indigo1 Amsterdam) }\end{array}$ \\
\hline & & 11 & $/ 3-5 y$ & $35 \ldots 45$ & $\begin{array}{c}\text { Between } 7 \text { et } 18 \text { y before } \\
\text { the youngest cancer. } 4 \\
\text { Amsterdam, } 6 \text { in the research } \\
\text { protocol DOCC }\end{array}$ \\
\hline & & 1 & $/ 3 y$ & 40 & $\begin{array}{l}10 \mathrm{y} \text { before the youngest } \\
\text { cancer. }\end{array}$ \\
\hline & & 3 & 1 control & & 2 indigo, 1 duodeno \\
\hline & gastroscopy & 2 & 1 control & & $\begin{array}{l}1 \text { cancer at } 38 \text { y and, one } \\
\text { gastric cancer in } 1^{\text {st }} \text { and } 2^{\text {nd }} \\
\text { degree relative }(>60 \mathrm{y})\end{array}$ \\
\hline & Vaginal echography & 1 & & & \\
\hline & nothing & 6 & & & $\begin{array}{l}4 \text { study inclusion in the } \\
\text { research protocol DOCC }\end{array}$ \\
\hline & other & & & & \\
\hline & \multicolumn{5}{|c|}{2 proband: endometrial cancer at 55 and $69 \mathrm{y}, 11^{\text {st }}$ degree relative at $48 \mathrm{y}:$ no recommendation } \\
\hline & \multicolumn{5}{|c|}{5 cases: stomach, $1^{\text {st }}$ degree relative $(78 \mathrm{y}), 2^{\text {nd }}(38 \mathrm{y}), 3^{\text {rd }}$ (age?): no recommendation } \\
\hline \multirow{3}{*}{ To test $(11 / 59)$} & Nothing & 8 & & & Running test \\
\hline & \multirow{2}{*}{ Colonoscopy } & 1 & $15 \mathrm{y}$ & 30 & Running test \\
\hline & & 2 & 1 control & & Running test \\
\hline
\end{tabular}

Care management decision: For all 8 of the 15 cases described above as not meeting criteria but found to carry an MMR gene mutation, surveillance following the Lynch syndrome protocol was recommended for the $1^{\text {st }}$ degree relatives (colonoscopy every 2 years for all beginning at age 20 years old and vaginal echography in women every year beginning as age 30 years old). For 2 carrier cases, a gastric exploration with gastroscopy was recommended every 2 years. No gastric cancer cases were observed in these families.

For the other 7 non carrier cases, Lynch-like surveillance was recommended for 1 case (colon cancer at 43 years old for the index case but no other cancer history reported in the family), beginning at age 20 years old. For 1 case, a colonoscopy every 3 years was recommended. For 1 case, a renal echography at 30 years old was recommended (urothelial cancer observed in a third degree relative). No additional surveillance protocols were recommended in the 4 remaining cases.

For the 33 cases for whom genetic testing was not recommended, Lynch-like surveillance was recommended in 2 cases, 1 exploration by colonoscopy in 4 cases, and no additional surveillance for the remaining cases. Concerning gastric surveillance, there is no clear and written consensus among professionals. Furthermore, we are also not aware of studies which confirm the benefits of urinary tract surveillance. The decisions regarding these forms of management are best supported by referrals to gastroenterology specialists.

\section{Group 2: RER+/IHC- Cases: 8 family cases}

Genetic analysis Indication: For 5 cases, Bethesda criteria were sufficient to recommend testing of the $M M R$ genes. This table corresponds to the case of group 1): Amsterdam and Bethesda seem to confer a good positive predictive value.

It also seems that combining Amsterdam criteria and positive somatic testing (RER+ with IHC+ or IHC-) results in a very good positive predictive value. Nevertheless, a much larger-scale study needs to be carried out, in which a larger sampling of family cases with genetic test results is available to confirm or invalidate this hypothesis.

Care management decision: In 4 of these 5 cases, an MMR mutation was identified. Members of these families were recommended to follow Lynch-like surveillance as previously described. The remaining noncarrier case was also recommended a Lynch-like surveillance protocol 
because the RER+ phenotype conferred elevated risk. Concerning gastroscopy, the current professional consensus is undetermined and will probably merit a specific debate.

\section{Group 3: RER-/IHC- cases: 59 family cases}

Genetic analysis indication: Only 11 of the 59 cases received genetic testing and no $M M R$ mutations were identified in any of these. Among them, 8 met Bethesda criteria. The 3 remaining family cases did not meet either Bethesda or Amsterdam criteria (there were: 1 isolated case at 54 years / 1 healthy case whose father has multiple primitive tumour at age 50 years / and 1 case with adenomatous colorectal polyps and one $2^{\text {nd }}$ degree relative with colorectal cancer).

For 11 cases, we recommended gene test ( 2 met Amsterdam criteria, 6 met Bethesda criteria, and 3 met no criteria). For the remaining 37 family cases, the recommendation of gene testing was not indicated. Care management was defined. Among these cases, 6 met Amsterdam criteria and 23 met Bethesda criteria. The remaining cases met neither criteria. Further discussion on the 6 cases was held to understand why genetic testing was not proposed and to confirm care management.

Care management decision: For the 11 non-carrier family cases, familial surveillance recommended was colonoscopy every 2 years beginning at age 20 years $(\mathrm{N}=2)$; every 3 years from age 20-30 years old $(\mathrm{N}=4)$; every 3-5 years from $30-40$ years old $(\mathrm{N}=2)$; and every $5 \mathrm{y}$ beginning at age 30 years old $(\mathrm{N}=3)$. In these cases, surveillance for $1^{\text {st }}$ degree relatives do not depend on the age of the youngest cancer in the family. We also observed 2 cases in which a recommendation of vaginal echography was made despite not seeing a history of uterine cancer in the family.

For the 37 cases not receiving genetic testing, surveillance recommended to relatives was variable: colonoscopy every 5 years from $20-45 y$ ( $N=13)$; every 3-5 years from $35-45$ years old $(\mathrm{N}=11)$; and every year from 40 years old $(\mathrm{N}=1)$; single baseline colonoscopy $(\mathrm{N}=3)$. No additional surveillance was recommended for the remaining cases. In general, the surveillance was recommended to begin starting between 2 and $18 \mathrm{y}$ before the youngest colorectal cancer case in the family.

Uterine echography recommendations were similarly variable. The procedure was recommended in 1 case in which the family did not show endometrial cancer, however it was not recommended in 2 cases in which the proband presented with endometrial cancer (at 55 and 69 years old, respectively) and in an additional case where a $1^{\text {st }}$ degree relative was observed to have endometrial cancer at 48 years of age. In 2 cases, control by gastroscopy was proposed.
Decision-making by the MDCs were therefore observably heterogeneous and patient care management was inconsistent. A global overview of criteria that allows for decision-making regarding whether or not to recommend $M M R$ gene analysis is shown on table 3. This has not currently been implemented as a national strategy.

\section{EQID tool creation and validation}

Overall, we observed heterogeneity of the recommendations made by the MDC in Groups 2 and 3. As for the Group 1, (RER+/IHC+), when families with positive somatic tests are considered to be "at (high) risk", the recommendation to implement a Lynch-type surveillance plan should be considered whatever the familial context.

Through this study, we observed a heightened awareness of our work during the MDC. In particular, we noted the difficulties that are encountered and the discrepancies that occur in our decision-making process. The work provided by the members of the MDC is not trivial. Cases are dealt with on an individual basis and at varying dates. Therefore, it is not unusual, given the absence of a standardization of the process, that differences will exist in the patient care recommendations that are made.

Therefore, we propose an easy-to-use database that can be diffused regionally or even more globally. This database consists of four chapters (proband information, family history, genetic status, and surveillance recommendation) using drop-down menus to simplify the synthesis of data needed for decision-making. For each drop-down menu, a list of response choices is provided. These responses are those generally found in MDC conclusions based on our cohort. A free-text field is also available for cases where the answer could be different or needs to be clarified (Figure 3).

It is not easy to standardize every decision-making (due to time, upsurge of new technologies), and the final goal is to improve patients and families follow-up, for an optimal quality of care management.

\section{Conclusion}

Colorectal cancer is a public health issue. Because it can be inherited, a diagnosis may have implications for both the patient and his or her relatives. To facilitate patient care management, French hospitals utilize multidisciplinary committees in certain cases. MDCs enable professionals and experts to optimize decision-making, taking into account relevant expert advice. In response to the observation of discordance of decisions made within MDCs, we developed a computerized system to aid in standardization of the decision-making

Table 3. Overview of criteria which allow to validate or not a genetic analysis. MMR: Mismatch Repair genes

\begin{tabular}{|c|c|c|c|c|}
\hline Nb of cases met criteria & Amsterdam II & Bethesda & none & \\
\hline \multirow{4}{*}{ RER+/IHC+ } & 2 & 4 & 2 & tested MMR + \\
\hline & & 6 & 1 & tested MMR - \\
\hline & 1 & 20 & 12 & Not tested (to discuss) \\
\hline & 1 & 19 & 5 & To test \\
\hline \multirow{4}{*}{ RER+/IHC- } & 3 & 1 & & tested MMR + \\
\hline & & 1 & & tested MMR - \\
\hline & & & & Not tested \\
\hline & & 3 & & To test \\
\hline \multirow{4}{*}{ RER-/IHC- } & & & & tested MMR + \\
\hline & & 8 & 3 & tested MMR - \\
\hline & 6 & 23 & 8 & Not tested (no indication) \\
\hline & 2 & 6 & 3 & To test \\
\hline
\end{tabular}

IHC-: no loss of MMR protein expression. 


\section{Different chapters :}

\section{En-tête administratif}

No Famille

No Extérieur

Proposant

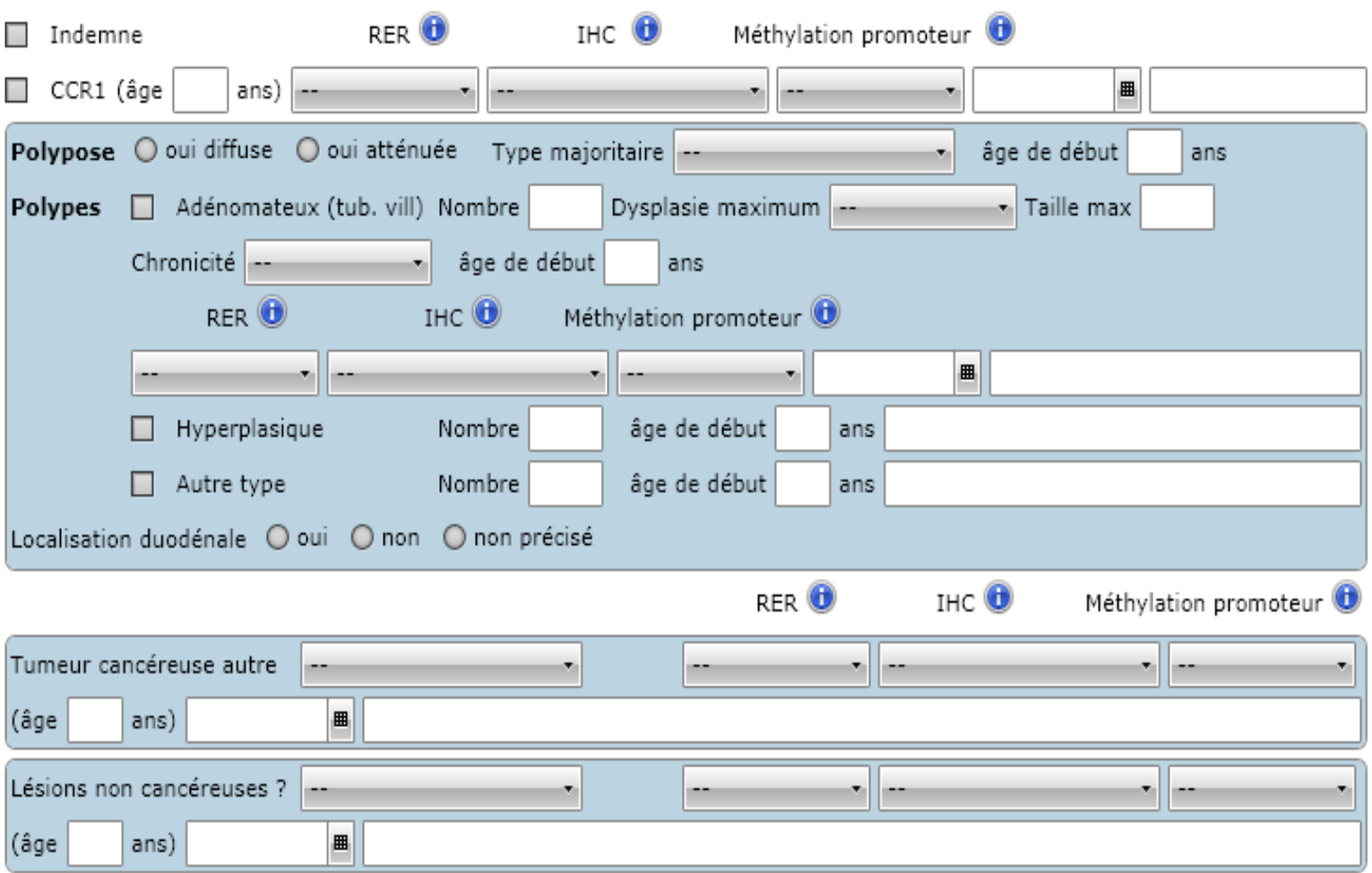

Famille

RER (1) IHC (i) Méthylation promoteur (i)

\begin{tabular}{|c|c|c|c|c|c|}
\hline Parenté (1) -.- & âge de début & ans & - & 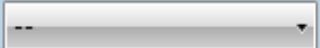 & - \\
\hline \multicolumn{6}{|c|}{ Type de tumeur -- } \\
\hline 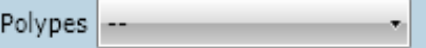 & âge de début & ans & $-\cdot$ & -- & -- \\
\hline Dysplasie max si adénome & - Nombre & & & & \\
\hline
\end{tabular}

\section{Génétique}

Cas index $\longrightarrow$ Gène $\longrightarrow$ - $\square$

Surveillance

\begin{tabular}{|c|c|c|c|c|c|}
\hline \multicolumn{2}{|c|}{ Qui ? - } & Type de surveillance & -- Examen & $--\quad$ Rythme & -- \\
\hline âge de début & ans & & & & \\
\hline Chirurgie? & 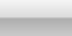 & - Référe & entiel ? -- & - & \\
\hline
\end{tabular}




\section{Proban:}

\begin{tabular}{l|l|}
\hline Polyposis : & Choose yes/no \\
- yes diffuse \\
- yes attenuated \\
- yes ? \\
- no
\end{tabular}

Majority type
- adenomatous
- hyperplastic
- juvenile
- scalloped
- hamartomatous
- other

polypes :
max dysplasia
- High
- Low
- Unspecified

Chronicity
- synchronous
- metachronous
- not defined

- other

Duodenal localization

\begin{tabular}{|l||l|}
\hline choose & \begin{tabular}{|l} 
other cancerous tumor \\
yes \\
unspecified
\end{tabular} \\
& - digestive \\
- endometrium \\
- desmoid \\
- cutaneous \\
- cerebral \\
- endometrioid ovary \\
- other
\end{tabular}

Non-cancerous lesions?

- Benign skin lesion

- other

- no

- not specified

\section{Family:}

\begin{tabular}{|l||l}
\hline relationship* & $\begin{array}{l}\text { type of tumor } \\
\text { - 1(father) }\end{array}$ \\
- - colorectal cancer \\
- 1(children) & - endometrium cancer \\
- 1(siblings) & - stomach cancer \\
- 2(paternal uncles/aunts) & - skin cancer \\
- 2(maternal uncles/aunts) & - desmoid tumor \\
- 3(paternal grand- & - brain tumor \\
parents/1st cousins) & - benign cutaneous lesion \\
- 3(maternal grand- & - other \\
\hline parents/1st cousins) &
\end{tabular}

\begin{tabular}{|l|l|}
\hline polyps & Dysplasia if adenomatous \\
- adenomatous & - High \\
- hyperplastic & - Low \\
- juvenile & - Unspecified \\
\hline
\end{tabular}

- scalloped

- hamartomatous

- other

parents $/ 1^{\text {st }}$ cousins)

- 4 and more (maternal grand-parents' hand) - 4 and more (paternal grand-parents' hand)

*information « $\mathrm{i} »: 1,2,3,4$ correspond to degre of relationship between patient and proban.

\section{RER Statut}

- MSS (miscrosatellite stability)

- MSI (miscrosatellite instability)

- MSI-high

- MSI-low

- failure

- impossible

- in progress

- to do

\begin{tabular}{l}
\hline Expression of proteins in IHC \\
- persistence \\
- loss (specify) \\
- heterogeneous (specify) \\
- failure \\
- impossible \\
- in progress \\
- to do
\end{tabular}

\begin{tabular}{l} 
date of test \\
....... \\
\hline
\end{tabular}

Methylation of promoter

- yes

- no

- failure

- impossible

- In progress

- to do 


\section{Genetic :}

\begin{tabular}{|l|}
\hline Relatives* \\
-1 (father) \\
-1 (mother) \\
-1 (children) \\
-1 (siblings) \\
- 2(paternal \\
uncles/aunts) \\
- 2(maternal \\
uncles/aunts) \\
-3 (paternal grand- \\
parents/1st cousins) \\
-3 (maternal \\
grand-parents/1 1 st \\
cousins) \\
-4 and more \\
\hline
\end{tabular}

\section{Surveillance :}

\begin{tabular}{|l|l|}
\hline gene & \\
- no mutation of MMR & \\
- MMR in progress & - PMS2 mutation \\
- MMR to test & - PMS2 variant \\
- MLH1 mutation & - no mutation of APC \\
- MLH1 variant & - APC mutation \\
- MSH2 mutation & - APC in progress \\
- MSH2 variant & - APC to test \\
- MSH6 mutation & - no mutation of MYH \\
- MSH6 variant & - MYH mutation \\
- & - MYH in progress \\
& - MYH to test \\
\hline
\end{tabular}

\begin{tabular}{|l|l|}
\hline $\begin{array}{l}\text { Who ? } \\
\text { - proban } \\
\text { - relatives }\end{array}$ & $\begin{array}{l}\text { type of surveillance } \\
\text { - type Lynch (i) } \\
\text { - type polyposis (i) }\end{array}$ \\
\hline
\end{tabular}

\begin{tabular}{|l|}
\hline Examination \\
- coloscopy \\
- gastroscopy \\
- H.Pylori \\
- chromoendoscopy with \\
indigo carmen \\
- Pelvic ultrasound \\
- duodenoscopy \\
- gastric cartography \\
\hline
\end{tabular}

\section{rhythm}

- 1 control

$-/ 1 \mathrm{yr}$

$-/ 2$ yrs

- / 3-5yrs

$-/ 5$ yrs

\footnotetext{
Surgery?

- prophylactic uterus

- ovarian prophylaxis

- right colectomy

- left colectomy

- subtotal colectomy

- gastrectomy

- other

- no surgery
}

(i) referential?

- INCA (cancer national institute) 2009 recommendations

- ... to complete when new recommendations 2017

Figue 3. bdd: EQID database

process. and diffused it to every collaborating partner of our MDC. By comparing how decisions were made among different groups of patient families, we were able to differentiate and categorize surveillance protocol recommendations. It appears indeed paramount to establish homogenous groups of patients/families through pedigrees in order to judiciously manage and follow-up with care. As a result, we targeted a better rationalization of care management and family prevention. Further studies are necessary to evaluate the quality control of our work by testing the software against fictive pedigrees, discussing them within MDCs, and comparing decisions with those previously given.
The EDIQ system is thus essential and will allow for the formalization and standardization of our MDC's decision-making process in patient cases. Based on our initial observations, it will be important to perform further studies at a national level to evaluate and improve the quality and consistency of decision-making processes in other MDCs as well.

This should also help us to improve the quality of genetic counselling provided to patients and their families. Somatic testing (RER/IHC) remains an important step prior to the decision by the $\mathrm{MDC}$ to recommend genetic testing for colorectal cancer related genes. 
We need to prescribe somatic testing more often, even if there is not a familial context of predisposition. In France, these analyses are underused (less than $30 \%$ of testing is made for newly diagnosed colorectal cancer, because of old tumour, no availability of medical professional, or maybe ignorance). These tests are not more expensive than a genetic test and this approach could, therefore, avoid genetic testing if the tumour phenotype is not in favour of hereditary predisposition.

We also studied PREMM1.2.6, a software that provides mutation risk calculation for Lynch syndrome. A threshold of $5 \%$ validates $M M R$ gene test indication. We highly recommend it [5].

\section{Acknowledgment}

We are grateful to all participants for their collaboration and their availability, notably members of MDCs of the Lyon Region. The experiments comply with the current French laws.

\section{References}

1. Lipton LR, Johnson V, Cummings C, Fisher S, Risby P, et al. (2004) Refining the Amsterdam Criteria and Bethesda Guidelines: testing algorithms for the prediction of mismatch repair mutation status in the familial cancer clinic. J Clin Oncol 22: 49344943. [Crossref]

2. Half E, Bercovich B, Rozen,P (2009) Familial adenomatous polyposis. Orphanet $J$ Rare Dis 4: 22. [Crossref]

3. Aissaoui S, Aissaoui H, Giraud S, Pinson S, Calender A (2014) Development of multidisciplinary committees for decision making and care management in hereditary colon cancer: the French state of the art. J Community Genet 5: 185-189. [Crossref]

4. Lynch HT, Riley BD, Weismann S, Coronel SM, Kinarsky Y, Lynch JF, et al. (2004) Hereditary nonpolyposis colorectal carcinoma (HNPCC) and HNPCC-like families Problems in diagnosis, surveillance, and management. Cancer 100: 53-64. [Crossref]

5. Aissaoui S, Cartellier C, Seytier T, Giraud S, Calender A (2017) Genetic mutation risk calculation in Lynch syndrome inheritance: Evaluating the utility of the PREMM1,2,6 Model in Lyon: the first French study. Bull Cancer 104: 288-294. [Crossref]

Copyright: (2019 Aissaoui S. This is an open-access article distributed under the terms of the Creative Commons Attribution License, which permits unrestricted use, distribution, and reproduction in any medium, provided the original author and source are credited. 